\title{
Apparent and content validation of maternal self-efficiency scale for prevention of childhood diarrhea
}

\author{
Emanuella Silva Joventino ${ }^{1}$ \\ Mônica Oliveira Batista Oriá2 \\ Namie Okino Sawada ${ }^{3}$ \\ Lorena Barbosa Ximenes ${ }^{4}$
}

\begin{abstract}
Aim: The aim of this paper is to describe the apparent and content validation for the Maternal Self-Efficiency Scale for the Prevention of Childhood Diarrhea. Method: Methodological study with the execution of apparent and content validation by seven judges; semantic analysis, by 30 mothers of children under 5 years old and also a pre-test involving 31 mothers who have been selected through convenience. It has been considered necessary to have the agreement of at least $70 \%$ of the judges for apparent validation and a minimum of $80 \%$ for pertinence and Index of Content Validation. Results: This paper shows that most items have been considered clear, comprehensive and relevant by the judges. The final Content Validity Index of the scale was 0.96. The suggestions of the mothers were accepted. Conclusion: The scale ended up having 25 items and two domains (family hygiene and general/eating practices) which assess the maternal selfefficiency for the prevention of diarrhea in their children, thereby contributing to the planning of nursing interventions.
\end{abstract}

Descriptors: Diarrhea, Infantile; Self Efficacy; Nursing Methodology Research; Validation Studies.

\footnotetext{
${ }^{1}$ Doctoral student, Universidade Federal do Ceará, Fortaleza, CE. Brasil. Scholarship holder from Conselho Nacional de Desenvolvimento Científico e Tecnológico (CNPq).

2 PhD, Adjunct Professor, Departamento de Enfermagem, Universidade Federal do Ceará, Fortaleza, CE. Brazil.

${ }^{3} \mathrm{PhD}$, Associate Professor, Escola de Enfermagem de Ribeirão Preto, Universidade de São Paulo, WHO Collaborating Centre for Nursing Research Development, Ribeirão Preto, SP, Brasil.

${ }^{4} \mathrm{PhD}$, Associate Professor, Departamento de Enfermagem, Universidade Federal do Ceará, Fortaleza, CE. Brazil.
} 


\section{Introduction}

Childhood diarrhea is the second most important cause of death among children aged under 5 years, affecting some 1.5 million children per year(1). In Brazil, between 1995 and 2005, there were 39,421 deaths caused by diarrhea and $1,505,800$ admittances to hospital for reasons associated with this illness, among children in their first year of life(2).

The causes of childhood diarrhea are many, with behavioural factors usually playing a part. Thus, the role of the family, and especially of the mother, is recognised in the care that is provided to the children, considering that this illness is the best example of a situation where knowledge and appropriate attitudes by the mothers in relation to the appropriate handling of the illness in their offspring have an effective influence on reduction of the associated complications ${ }^{(3)}$.

In the light of this fact, apart from the awareness of the measures that can be taken to prevent the onset of diarrhea, it is also essential to consider maternal selfefficiency in the care which is provided to the children, as the same factor acts upon people encouraging them to transform their action, having an influence on the events which affect their lives, the quantity of effort that shall be made and the time they shall persist to overcome obstacles and adverse experiences(4). Selfconfidence does not necessarily guarantee success, but on the other hand, lack of self-confidence is sure to produce failure(5).

It is therefore important to know the selfefficiency of each individual person so that there may be an appropriate intervention in personal confidence, identifying people with low self-efficiency scores and with the implementation of strategies that modify this perception, with a view to improving emotional, physical and social adjustment ${ }^{(6)}$.

It therefore becomes evident that there is relevance in the use of instruments that assess maternal selfefficiency in relation to prevention of child diarrhea, promoting the general health of the child. Thus, the aim of this paper is that of describing the apparent and content validation of the Maternal Self-Efficiency Scale for the Prevention of Child Diarrhea (Escala de Autoeficácia Materna para a Prevenção da Diarreia Infantil - EAPDI).

\section{Methods}

This is a methodological study which has adopted the recommended psychometric procedures ${ }^{(7-8)}$ to construct the EAPDI, which includes three specific points (the theoretical, the empirical and the analytic); however, in this study we have only included the theoretical and analytical poles, in relation to the apparent and content validity, which are stages also carried out by other authors ${ }^{(9)}$.

In the beginning, it was sought to identify and deepen the construct of "prevention of childhood diarrhea", an essential step for the construction of constitutive and operational definitions, which precede the operationalization of the items and the domains that make up the instrument ${ }^{(7)}$. This stage was carried out through the study of publications that mention preventive measures against childhood diarrhea, indexed in four large databases ${ }^{(10)}$.

After a theoretical explanation about the construct, as also the definition thereof, the process forged ahead with the preparation of the items and construction of the instrument. Here we must mention that, in the bibliographical study as made, there was no identification of any study that addressed the issue of maternal selfefficiency in the prevention of diarrhea in young children, or even one that mentioned the construction or the use of some scale or instrument for measurement of this construct.

Also considering the fact that, to reach the latest version of the EAPDI, there was a passage through several stages, leading to six different versions of the scale, it was decided to represent this methodological path through a scheme which specifies each version of the scale and its respective quantity of items (Figure 1 ). 


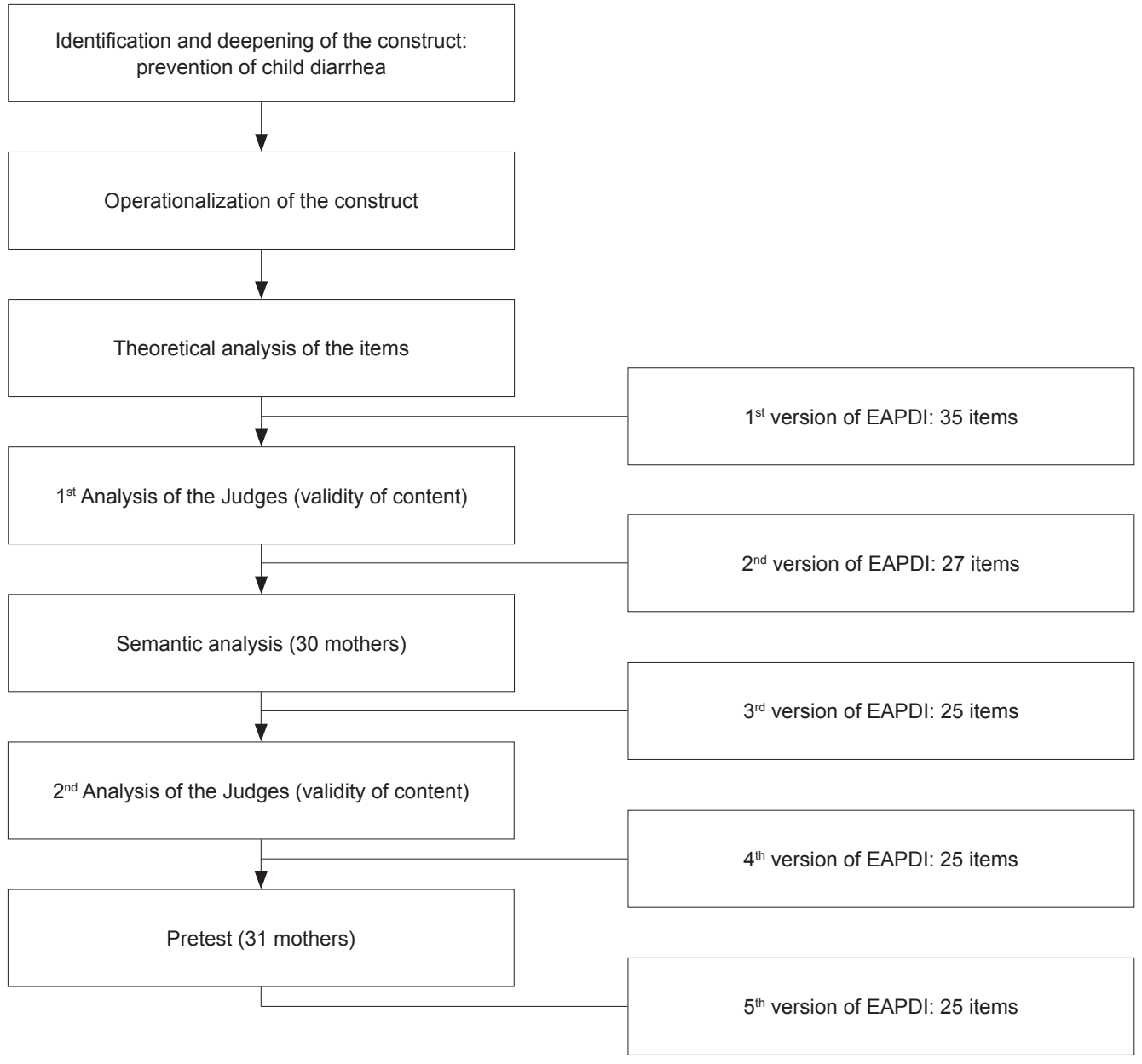

Figure 1 - A graphical representation of the stages of construction and validation of the Maternal Self-Efficiency Scale for the Prevention of Child Diarrhea (Escala de Autoeficácia Materna para Prevenção da Diarreia Infantil - EAPDI). Fortaleza, CE, Brazil, 2010

To proceed with the validation of content, it is essential to have each item analysed by a team of judges, considered specialists in the concept here studied, and six judges shall suffice ${ }^{(8)}$. However, by means of snowball sampling, it was possible to select a panel of seven judges, which made it easier to establish tie-breaks for different opinions, and these obtained a minimum score of five points according to criteria adapted for a selection of experts ${ }^{(11-12)}$.

In the instrument used for the analysis of the first version of the scale, the 35 items were allocated in a way that the judges could proceed with the respective appraisal in terms of clarity and understanding, and the listing of the items with a scale construct and the corresponding domain, and also the relevance of each item (irrelevant, slightly relevant, really relevant and strongly relevant) ${ }^{(13)}$. In addition, this instrument also had a place for suggestions made by the judges.
In relation to the apparent validity, items were considered as clear and understandable when they had the agreement of at least $70 \%$ of the judges ${ }^{(14)}$. Items were considered pertinent and relevant (Content Validity Index Índice de Validade de Conteúdo - IVC) when they achieved a 0.8 score in agreement between the judges, meaning that the items that did not reach this percentage were removed from the second version of the instrument $(7,13)$.

After the first version of the instrument was critically reviewed by the judges, the second version of the scale thus originated (27 items), and this was then subjected to a process of semantic analysis in July 2009 , with the analysis being executed by 30 mothers of children aged under 5 years old, in the city of Fortaleza, State of Ceará, Brazil, by means of house visits with the lowest stratum of the target public (7).

After this stage of semantic analysis, some changes were made to the items on the scale, and two items 
were removed. Thus, the third version of the scale became made up of 25 items (Figure 1). To obtain a new adaptation of the items, it was decided to embark on a second validation phase with the same judges used in the first phase, which was considered as an analysis by sophisticated sample, to improve the wording of the items.

Once the changes suggested by the judges were implemented, and considering the IVC of each one, we obtained the fourth version of the scale (25 items) which was subjected to a pre-test, being applied to another sample of 31 mothers of children aged less than five years of age.

During the pre-test, the difficulties and observations of the mothers were taken into account by the researchers, thereby leading to readjustments and adaptations, which in turn led to the fifth version of the scale, which is the pilot instrument which kept its total of 25 items.

This study was approved by the Research Ethics Committee of the Federal University of the Ceará (Universidade Federal do Ceará - UFC), under protocol No. 92/09, in compliance with Resolution No. 196/96 of the National Health Council. All the participants signed a Declaration of Free and Clarified Consent.

\section{Results}

By means of a search in the literature and also the analysis of 82 studies, we identified 35 operational definitions of preventive measures against child diarrhea which depend on maternal care, which have been turned into items prior to EAPDI. It was observed that these items were included in four broad domains: the child's hygiene (Figure 2), eating practices (Figure 3), maternal behaviour (Figure 4) and the domestic environment (Figure 5).

The options for answering the EAPDI were grouped with the aid of a Likert five-point scale ( $1=$ totally disagree, 2 = disagree; $3=$ sometimes agree; $4=$ agree; 5 = strongly agree); the mother shall answer by choosing only one option, with the total score of the subject established by the sum of the scores corresponding to each answer, so that the total score may vary between 25 and 125. Mothers with higher scores are those with a higher level of self-efficiency in the prevention of child diarrhea.

\begin{tabular}{|c|c|c|c|c|}
\hline \multicolumn{2}{|r|}{$1^{\text {st }}$ Version } & \multicolumn{3}{|c|}{$5^{\text {th }}$ Version } \\
\hline $\mathbf{N}^{\circ}$ & Items & $\mathbf{N}^{\circ}$ & Items & Domain \\
\hline 1 & $\begin{array}{l}\text { I manage to get my child to wash his or her hands with } \\
\text { soap before meals. }\end{array}$ & 1 & $\begin{array}{l}\text { I can get my child to wash his or her hands with water } \\
\text { and soap before meals. }\end{array}$ & $\begin{array}{l}\text { General / Food } \\
\text { Practices }\end{array}$ \\
\hline 12 & $\begin{array}{l}\text { I manage to give my child at least one bath/shower a } \\
\text { day }\end{array}$ & 9 & $\begin{array}{l}\text { I am able to give my child more than one bath/shower } \\
\text { a day. }\end{array}$ & Family Hygiene \\
\hline 14 & $\begin{array}{l}\text { I manage to stop by child putting dirty objects into his } \\
\text { or her mouth. }\end{array}$ & 11 & $\begin{array}{l}\text { I can prevent my child putting dirty objects into his or } \\
\text { her mouth. }\end{array}$ & Family Hygiene \\
\hline 20 & $\begin{array}{l}\text { I can get my child to wash his or her hands after } \\
\text { touching animals. }\end{array}$ & \multicolumn{3}{|c|}{ Excluded: IVC $<0.8$} \\
\hline 23 & I can keep my child's nails short and clean. & 17 & I am able to cut my child's nails when necessary. & Family Hygiene \\
\hline 27 & $\begin{array}{l}\text { I always put the clothes to be washed, after my child } \\
\text { has used them during the day. }\end{array}$ & \multicolumn{3}{|c|}{ Excluded: IVC $<0.8$} \\
\hline \multirow{2}{*}{32} & \multirow{2}{*}{$\begin{array}{l}\text { I manage to keep my child using shoes whenever he } \\
\text { or she is outside the home. }\end{array}$} & 22 & $\begin{array}{l}\text { I am able to keep my house clean before my child } \\
\text { walks or plays on the floor.* }\end{array}$ & Family Hygiene \\
\hline & & 23 & $\begin{array}{l}\text { I am able to keep my child wearing shoes outside the } \\
\text { home. }\end{array}$ & Family Hygiene \\
\hline
\end{tabular}

* Item added after the $1^{\text {st }}$ analysis by the judges, in the second version of the scale

Figure 2 - Distribution of the items according to the hygiene domain, in line with the first version of EAPDI, related to the other domains in the 5th version of EAPDI. Fortaleza, CE, Brazil, 2010 


\begin{tabular}{|c|c|c|c|c|}
\hline \multicolumn{2}{|r|}{$1^{\text {st }}$ Version } & \multicolumn{3}{|c|}{$5^{\text {th }}$ Version } \\
\hline $\mathbf{N}^{\circ}$ & Items & $\mathbf{N}^{\circ}$ & Items & Domain \\
\hline 2 & $\begin{array}{l}\text { I manage to wash fruit and vegetables with sodium } \\
\text { hypochlorite. }\end{array}$ & 2 & $\begin{array}{l}\text { I am able to wash my fruit and vegetables with sodium } \\
\text { hypochlorite or sanitary bleach (água sanitária). }\end{array}$ & $\begin{array}{l}\text { General / Food } \\
\text { Practices }\end{array}$ \\
\hline 3 & $\begin{array}{l}\text { I can read the expiry dates of food products, before I } \\
\text { give them to my child. }\end{array}$ & 3 & $\begin{array}{l}\text { I can see the expiry period for the different food } \\
\text { products, before I offer them to my child. }\end{array}$ & $\begin{array}{l}\text { General / Food } \\
\text { Practices }\end{array}$ \\
\hline 6 & I manage to cover food and water at all times. & 6 & $\begin{array}{l}\text { I manage to cover food products and water after I have } \\
\text { helped myself. }\end{array}$ & Family Hygiene \\
\hline 10 & $\begin{array}{l}\text { I do not mix cooked and raw food on the same shelf in } \\
\text { the refrigerator. }\end{array}$ & \multicolumn{3}{|c|}{ Excluded: IVC $<0.8$} \\
\hline 11 & I manage to breast-feed my child for over 6 months. & 8 & I am able to breast-feed my child for over 6 months. & $\begin{array}{l}\text { General / Food } \\
\text { Practices }\end{array}$ \\
\hline 19 & $\begin{array}{l}\text { I manage to offer breast milk as the exclusive } \\
\text { nourishment to my child in his or her first } 6 \text { months of } \\
\text { life. }\end{array}$ & 14 & $\begin{array}{l}\text { I am able to offer breast milk as exclusive nourishment } \\
\text { to my child in his or her first } 6 \text { months of life. }\end{array}$ & $\begin{array}{l}\text { General / Food } \\
\text { Practices }\end{array}$ \\
\hline 31 & $\begin{array}{l}\text { I manage to offer a healthy diet to my child, once I } \\
\text { wean him or her off breast milk. }\end{array}$ & 21 & $\begin{array}{l}\text { I am able to offer my child a healthy diet after he or } \\
\text { she stops breast-feeding (Examples: fruit, vegetables, } \\
\text { meat, eggs, chicken, rice, beans) }\end{array}$ & $\begin{array}{l}\text { General / Food } \\
\text { Practices }\end{array}$ \\
\hline 35 & I can boil or filter the water we drink at home. & 25 & $\begin{array}{l}\text { I am able to boil or filter the drinking water, or I buy } \\
\text { bottled water to offer my child. }\end{array}$ & $\begin{array}{l}\text { General / Food } \\
\text { Practices }\end{array}$ \\
\hline
\end{tabular}

Figure 3 - Distribution of the items according to the food practices domain, according to the first version of EAPDI, related to the other domains in the $5^{\text {th }}$ version of EAPDI. Fortaleza, Ceará, Brazil, 2010

\begin{tabular}{|c|c|c|c|c|}
\hline \multicolumn{2}{|r|}{$1^{\text {st }}$ Version } & \multicolumn{3}{|c|}{$5^{\text {th }}$ Version } \\
\hline $\mathbf{N}^{\circ}$ & Items & $\mathbf{N}^{\circ}$ & Items & Domain \\
\hline 4 & $\begin{array}{l}\text { I always wash my hands with soap before preparing, } \\
\text { handling and eating food. }\end{array}$ & 4 & $\begin{array}{l}\text { I wash my hands with water and soap before preparing } \\
\text { and handling food. }\end{array}$ & Family Hygiene \\
\hline 7 & $\begin{array}{l}\text { I can keep my hair clean and tied back while I am } \\
\text { preparing food for my child. }\end{array}$ & \multicolumn{3}{|c|}{ Excluded: IVC $<0.8$} \\
\hline 9 & $\begin{array}{l}\text { I can monitor the growth and development of my child, } \\
\text { taking him or her to the appropriate health services. }\end{array}$ & 7 & $\begin{array}{l}\text { I am able to take my child to the health services even } \\
\text { when he or she is not ill. }\end{array}$ & $\begin{array}{l}\text { General / Food } \\
\text { Habits }\end{array}$ \\
\hline 13 & $\begin{array}{l}\text { I can wash my hands with soap before feeding my } \\
\text { child. }\end{array}$ & 10 & $\begin{array}{l}\text { I am able to wash my hands with soap and water } \\
\text { before feeding my child. }\end{array}$ & Family Hygiene \\
\hline 15 & After consuming food, I can keep it in the refrigerator. & 12 & $\begin{array}{l}\text { I tend not to offer my child left-overs from previous } \\
\text { meals. }\end{array}$ & $\begin{array}{l}\text { General / Food } \\
\text { Habits }\end{array}$ \\
\hline 16 & I can wash my hands after handling money. & \multicolumn{3}{|c|}{ Excluded: IVC $<0.8$} \\
\hline 17 & $\begin{array}{l}\text { I always take my child to have his or her vaccinations, } \\
\text { up to the age of } 5 \text { years. }\end{array}$ & 13 & $\begin{array}{l}\text { I am able to take my child to be vaccinated, up to the } \\
\text { age of } 5 \text { years. }\end{array}$ & $\begin{array}{l}\text { General / Food } \\
\text { Habits }\end{array}$ \\
\hline 18 & $\begin{array}{l}\text { I can wash the soft drink containers and those of other } \\
\text { drinks with water before drinking. }\end{array}$ & \multicolumn{3}{|c|}{ Excluded: IVC < 0.8 . Not included in the semantic analysis stage. } \\
\hline 21 & I always boil my child's bottle, dummy or cup. & 15 & $\begin{array}{l}\text { I am able to wash my child's bottle, dummy or cup with } \\
\text { soap and water after each use. }\end{array}$ & Family Hygiene \\
\hline 22 & I wash my hands after handling the litter bin. & 16 & $\begin{array}{l}\text { I am able to wash my hands with soap and water after } \\
\text { handling the litter bin. }\end{array}$ & Family Hygiene \\
\hline 26 & $\begin{array}{l}\text { I always wash my hands with soap after going to the } \\
\text { bathroom. }\end{array}$ & 20 & $\begin{array}{l}\text { I am able to wash my hands with soap and water after } \\
\text { going to the bathroom. }\end{array}$ & Family Hygiene \\
\hline 29 & $\begin{array}{l}\text { I do not let my child come into contact with stray } \\
\text { animals. }\end{array}$ & \multicolumn{3}{|c|}{ Excluded: IVC $<0.8$} \\
\hline 34 & $\begin{array}{l}\text { I always wash my hands with soap, after cleansing my } \\
\text { child when he or she spends a penny or defecates. }\end{array}$ & 24 & $\begin{array}{l}\text { I am able to wash my hands with soap and water after } \\
\text { cleaning my child after he or she has spent a penny or } \\
\text { defecated. }\end{array}$ & Family Hygiene \\
\hline
\end{tabular}

Figure 4 - Distribution of the items by domain, according to maternal behaviour in the first version of EAPDI, related to the other domains in the $5^{\text {th }}$ version of EAPDI. Fortaleza, CE, Brazil, 2010 


\begin{tabular}{|c|c|c|c|c|}
\hline \multicolumn{2}{|r|}{$1^{\text {st }}$ Version } & \multicolumn{3}{|c|}{$5^{\text {th }}$ Version } \\
\hline $\mathbf{N}^{\circ}$ & Items & $\mathbf{N}^{\circ}$ & Items & Domain \\
\hline 5 & $\begin{array}{l}\text { I always manage to keep the places where I prepare } \\
\text { my food clean. }\end{array}$ & 5 & $\begin{array}{l}\text { I am able to keep clean the place where I prepare my } \\
\text { food. }\end{array}$ & Family Hygiene \\
\hline 8 & $\begin{array}{l}\text { I always manage to wash the objects in the kitchen of } \\
\text { my home, straight after use. }\end{array}$ & \multicolumn{3}{|c|}{ Excluded: IVC $<0.8$} \\
\hline 24 & $\begin{array}{l}\text { I manage to dispose of the litter of my home in closed } \\
\text { containers. }\end{array}$ & 18 & $\begin{array}{l}\text { I am able to throw the litter of my house away, in bags } \\
\text { that are tied up. }\end{array}$ & Family Hygiene \\
\hline 25 & $\begin{array}{l}\text { I manage to always keep my home clean by disposing } \\
\text { of the litter outside the home. }\end{array}$ & 19 & $\begin{array}{l}\text { I am able to keep my home clean by throwing away } \\
\text { the litter outside the home. }\end{array}$ & Family Hygiene \\
\hline 28 & $\begin{array}{l}\text { I manage to avoid the presence of insects and rats in } \\
\text { my home. }\end{array}$ & \multicolumn{3}{|c|}{ Excluded: Considered irrelevant by the mothers, in the semantic analysis phase } \\
\hline 30 & $\begin{array}{l}\text { I manage to keep the kitchen areas free from } \\
\text { remnants of food. }\end{array}$ & \multicolumn{3}{|c|}{ Excluded: IVC $<0.8$} \\
\hline 33 & $\begin{array}{l}\text { I can always dispose of the litter in an appropriate } \\
\text { location. }\end{array}$ & \multicolumn{3}{|c|}{ Excluded: Considered repetitive by the experts } \\
\hline
\end{tabular}

Figure 5 - Distribution of the items according to the domestic environment domain, according to the first version of the EAPDI, related to the other domains in the $5^{\text {th }}$ version of the EAPDI. Fortaleza, CE, Brazil, 2010

Here, we can see that the domain known as "food practices" had eight items (22.9\%), while the "domestic environment" had seven (20\%), "maternal behaviour" had $13(37.1 \%)$ and finally the "child's hygiene" domain had seven items $(20 \%)$. Out of the suggestions taken up, we have the exclusion of the behavioural domain, as this is a scale for maternal self-efficiency, meaning that all the items referred to their confidence in relation to several preventive behaviour patterns, as also to remove the environment domain as its items could be included in the other domains : family hygiene or general / food practices.

With the 35 items prepared, we carried out the first validation of content by the judges. A total of seven judges, with ages between 33 and 55 (mean of 40; standard deviation of 7.2), participated in the study. Five of the judges were female $(71.7 \%)$ and they mentioned experience in the diarrhea area between 3 and 30 years (mean $=12$ ) and three $(42.9 \%)$ also in the construction of scale systems. All the judges had master's degrees, and five also had doctoral studies, in areas of interest to the construct. The seven judges got more points than the established necessary minimum, having obtained an average of 11 points on the criteria.

In the analysis conducted in relation to apparent validation, which addressed the issues of clarity and understanding of each items, the items that were not considered clear or comprehensible by the judges were those numbered $3,6,10,18,25$ and 31 , as they had an agreement rate of less than $70 \%$, with item 18 having been considered the least clear and comprehensible by the judges $(\mathrm{N}=3 ; 42.9 \%)$; however, these were not excluded.

In relation to the pertinence of each item in relation to maternal confidence in the prevention of childhood diarrhea, it was seen that, out of the total universe of 35 items, only item 10 (I manage not to mix raw and cooked food on the same shelf in the refrigerator) was not considered relevant for the construct of the scale, having secured the confidence of only four of the judges (57.1\%).

In relation to the relevance of the item on the scale, we see that the presence of 29 items (82.9\%) on the scale was considered relevant by the judges, which means that only six items $(17.1 \%)$ should be removed from the scale, these being items 7, 8, 10, 25, 27 and 29.

The calculation of the global IVC of this first version of the scale gave a value of 0.84 , showing that this is representative of the content to be studied about the prevention of diarrhea in children. However, it was confirmed that nine items had individual IVC values below 0.8 (7, 8, 10, 16, 18, 20, 27, 29, 30). For this reason, eight items were removed from the scale.

Item 18 (I manage to wash soft drink containers and those of other drinks, before drinking) of the first version of the scale, despite having an IVC of less than 0.8 , was maintained in the second version of the scale as it was considered relevant for the prevention of diarrhea in children, from the standpoint of the researcher. In this way, the same was subjected to semantic analysis of the 
mothers so that, depending on the results found, the respective item could be either maintained or excluded from the scale.

In the light of the results obtained, seeking to make the items considered not clear or incomprehensible more appropriate, many of the suggestions raised by the judges were accepted, and even some items which had reached satisfactory agreement levels were restructured, seeking a better understanding thereof.

Comparing the domains selected by the judges for each item, and also the domains identified through the deepening of the operational definitions, we could see that only seven items (20\%) did not coincide in relation to the domains $(3,8,11,15,19,21,29)$. This means that such items were reworded to make the related domain more evident, with the exception of items 8 and 29 , which were excluded, having an IVC index of less than 0.8 .

In the semantic analysis of EAPDI, involving a section of the target population, we could observe that the mean age of the mothers was 31 years, and that they had an average of 8.3 years of schooling, living in a consensual relationship ( mean $=20,66.7 \%$ ), in homes with an average of five resident people with a per caput income of $\mathrm{R} \$ 160.00$.

It must also be mentioned that the great majority of the suggestions as proposed by the mothers who participated in the semantic analysis stage was accepted. Here we should also mention the fact that one of the mothers interviewed proposed a suggestion that was considered relevant in relation to the set of items, when it was mentioned that the fact that she could manage to show a certain behaviour pattern does not mean that she really feels capable of carrying out such a task or practice. For this reason, in the third version of the scale all the items would start with the phrase "I am able to". In this way, it became evident that the scale assessed maternal capacity, confidence, and self-efficiency, rather than other constructs. In addition, some items of the first version of the scale included the word "always" which was removed by the judges.

Some mothers reported that they managed to keep their children's nails short and clean, due to the fact that the child would bite his or her nails, a habit which is considered a risk factor for picking up worms, and hence getting diarrhea. Thus, in the third version of the scale the item was written in a more objective fashion: I am able to cut the nails of my child when necessary. In addition, the item stating "I manage to wash, with soap and water, the soft drink container and that of other drinks, before drinking" was removed, as it brought a lot of doubt among the mothers, confirming its irrelevance with IVC $<0.8$.

In the second analysis of the judges, these only assessed the relevance of the 25 items that remained. In this way, all the items ( $\mathrm{N}=25 ; 100 \%)$ was considered relevant by at least $85.7 \%$ of the judges, so that they obtained the minimum acceptable level of $80 \%$ and, therefore, remained on the scale. We must also highlight the fact that the other items were considered as of relevant presence of the scale by all the judges $(N=7$; $100 \%)$. The total IVC of the scale rose from 0.86 , on the first analysis made by the judges, to 0.96 in this second analysis. It must be stressed that the IVC intervals identified for individual items ranged from 0.285 to 1 , in the first analysis, and 0.857 to 1 , in the second analysis made by the judges.

Next, the EAPDI was subjected to a pre-test of 31 mothers who had a mean age of 32 years, an average of 8.5 years of schooling, lived in a consensual relationship $(\mathrm{N}=19 ; 61.3 \%)$, with most being homemakers $(\mathrm{N}=21$; $67.7 \%)$. On average, each home had five residents, with a per caput income that came to $\mathrm{R} \$ 138.54$.

The application of the scale to the pre-test took an average of seven minutes. The item "I am able to give my child at least one bath a day" generated some doubts among the mothers, as some did not pay attention to the term "at least" and answered that they totally disagreed or disagreed, but soon after they complemented this fact with the comment "I give much more than just one bath a day, as it is always very hot here". Thus, the item was reworded to the following: I am able to give my child more than one bath a day.

In the case of the item "I am able to scald the bottle/dummy/cup used by my child after each use", some mothers said that they had watched a news report on television about a toxic substance which would come off the plastic used in bottles when these were subjected to high temperatures. Because of this, the item became: "I am able to watch my child's bottle/dummy/cup with soap and water after each use". Having made the alterations as mentioned and considering the apparent and content validations, the fifth version of the scale, which is the pilot instrument, continued with its 25 items in two domains.

\section{Discussion}

Considering that there are no scales that associate the variables of maternal self-efficiency and prevention 
of childhood diarrhea, the results cannot be discussed with comparison with similar scales, meaning that this is, indeed, an unprecedented study.

In the first analysis by the judges, item 3 (I can see the expiry date of the products before offering them to my child) was considered incomprehensible by these, but then it was changed and kept in the scale due to its relevance for the prevention of child diarrhea as suggested in the literature(15), in the same way that items 6 (I manage to cover food and water at all moments)(16), 25 (I manage to keep my home always clean by disposing of the litter outside the home)(16-17) and 31 (I manage to offer a healthy diet to my child once he or she is weaned off breast-feeding $)^{(15,18)}$.

Item 10 (I manage not to mix raw and cooked food on the same shelf in the refrigerator), an aspect which some authors mention as being relevant within the context of child diarrhea(19-20), was considered both difficult to understand and also not relevant to the construct of the scale, having been removed from the EAPDI, having obtained an IVC of less than 0.8 .

Item 18 (I manage to wash soft drink containers and those of other drinks before consumption)(16), which initially was not excluded from the scale, despite its IVC of less than 0.8 , was removed due to the controversy about the possibility of microbiological contamination on the outside of drinks packaging (bottles of polyethylene terephthalate (PET); aluminium cans; packages for chocolate drinks, fruit juices and yoghurts, among others) $)^{(21-22) \text {. }}$

Some items including the word "always" were also modified, based on the criterion of the mode for the construction of psychometric instruments ${ }^{(7)}$, according to which phrases with extreme statements must be avoided, as there is a Likert scale where the respondent may grade his or her choice.

During the pre-test phase, at the suggestion of the mothers, item 15 was modified due to the fact that, on subjecting some baby bottles to high temperatures, there is the release of Bisphenol A (BPA), an endocrine interferent which could have effects on pituitary, pancreatic and prostatic cells in mice, and also in human breast cancer cells ${ }^{(23)}$, causing a proneness to obesity, hyperplasia of the endometrium, abortions, diabetes, and also dysfunction of the liver, among other effects(24-25).

\section{Conclusion}

The conclusion reached is that the EAPDI has shown itself to be a valid scale from the standpoint of both face and content, and shall be considered within the context of assistance, as an instrument that is able to assess maternal self-efficiency in carrying out preventive measures against child diarrhea. In this regard, we highlight the need for intervention that takes self-efficiency into account, as this aspect is essential for the taking-up of healthy patterns of behaviour in the prevention of child diarrhea. Considering the relevance of the analytic pole, the other psychometric properties of the EAPDI are currently in the appraisal phase for later publication.

\section{References}

1. United Nations Children's Fund (UNICEF). World Health Organization (WHO). Diarrhea: why children are still dying and what can be done. Geneve: UNICEF/ WHO; 2009.

2. Oliveira TCR, Latorre MRDO. Tendências da internação e da mortalidade infantil por diarreia: Brasil, 1995 a 2005. Rev Saúde Pública. 2010;44(1):102-11.

3. Vanderlei LCM, Silva GAP. Diarreia aguda: o conhecimento materno sobre a doença reduz o número de hospitalizações nos menores de dois anos? Rev Assoc Med Bras. 2004;50(3):276-81.

4. Smith BJ, Tang KC, Nutbeam D. WHO health promotion glossary: new terms. Health Promot Int. 2006;21(4):340-5.

5. Bandura A. Self- efficacy: the exercise of control. New York: Freeman; 1997.

6. Salvetti MG, Pimenta CAM. Dor crônica e a crença de auto-eficácia. Rev Esc Enferm USP. 2007;41(1):135-40.

7. Pasquali L. Psicometria: teoria dos testes na psicologia e na educação. Petrópolis: Vozes; 2003.

8. Pasquali L. Princípios de elaboração de escalas psicológicas. Rev Psiquiatr Clín. 1998;25(5):206-23.

9. Perpina-Galvan J, Richart-Martinez M, CabaneroMartinez MJ, Martinez-Dura I. Content validity of the short version of the subscale of the State-Trait Anxiety Inventory (STAI). Rev. Latino-Am. Enfermagem. 2011;19(4):882-7.

10. Joventino ES. Construção e validação de escala para mensurar a autoeficácia materna na prevenção da diarreia infantil [dissertação]. Fortaleza (CE): Programa de Pós-Graduação em Enfermagem da Universidade Federal do Ceará; 2010.

11. Fehring RJ. The Fehring model. In: Carroll-Johson P. Classification of nursing diagnosis: proceedings of the tenth conference of North American Nursing Diagnoses Associations. Philadelphia: JB Lippincott; 1994. p. 55-7. 
12. Melo RP, Moreira RP, Fontenele FC, Aguiar ASC, Joventino ES, Carvalho EC. Critérios de seleção de experts para estudos de validação de fenômenos de enfermagem. Rev Rene. 2011;12(2):424-31.

13. Polit D, Beck CT. The Content Validity Index: are you sure you know what's being reported? Critique and recommendations. Res Nurs Health. 2006;29(5):489-97. 14. Pupulim JSL. Satisfação do paciente hospitalizado com sua privacidade física: construção e validação de um instrumento de medida [tese]. Ribeirão Preto (SP): Escola de Enfermagem de Ribeirão Preto da Universidade de São Paulo; 2009.

15. Araújo MFM, Ferreira AB, Gondim KM, Chaves ES. A prevalência de diarréia em crianças não amamentadas ou com amamentação por tempo inferior a seis meses. Cienc Cuid Saude. 2007;6(1):76-84.

16. Graf J, Meierhofer R, Wegelin M, Mosler RH. Water disinfection and hygiene behaviour in an urban slum in Kenya: impact on childhood diarrhea and influence of beliefs. Int J Environ Health Res. 2008;18(5):335-55.

17. Onyango-Oumaa W, Aagaard-Hansenb J, Jensenc BB. The potential of schoolchildren as health change agents in rural western Kenya. Soc Sci Med. 2005;61(8):1711-22.

18. Guerrant R, Oriá RB, Moore SR, Oriá MO, Lima $A A$. Malnutrition as an enteric infectious disease with long-term effects on child development. Nutr Rev. 2008;66(9):487-505.

19. Leite LHM, Machado PAN, Vasconcellos ALR, Carvalho IM. Boas práticas de higiene e conservação de alimentos em cozinhas residenciais de usuários do programa saúde da família-Lapa. Rev Ciênc Méd. 2009;18(2):81-8.

20. Towns RE, Cullen RW, Memken JA, Nnakwe NE. Food safety-related refrigeration and freezer practices and attitudes of consumers in Peoria and surrounding counties. J Food Prot. 2006;69(7):1640-5.

21. Dantas ST, Silva N, Dantas FBH. External microbiological contamination of beverages packaging. Braz J Food Technol. 2006;9(3):193-9.

22. Dantas ST, Silva N, Soares BMC, Souza JL. Comparative evaluation of the microbiological quality of cans of beverages, with and without aluminum seals. Braz J Food Technol. 2009;12(1/4):249-56.

23. Vom Saal FS, Akingbemi BT, Belcher SM, Birnbaum LS, Crain DA, Eriksen $M$ et al. Chapel hill bisphenol a expert panel consensus statement: integration of mechanisms, effects in animals and potential to impact human health at current levels of exposure. Reprod Toxicol. 2007;24(2):1-26.
24. Lang IA, Galloway TS, Scarlett A, Henl WE, Depledge $M$, Wallace RB et al. Association of urinary bisphenol A concentration with medical disorders and laboratory abnormalities in adults. J Am Med Assoc. 2008;300(11):1303-10.

25. Sugiura-Ogasawara M, Ozaki Y, Sonta S, Makino T, Suzumori K. Exposure to bisphenol a is associated with recurrent miscarriage. Hum Reprod. $2005 ; 20(8)$ :2325-9. 